\title{
JNPH
}

Volume 5 No. 2 (Desember 2017)

(C) The Author(s) 2017

\section{HUBUNGAN PEMANFAATAN SUMBER INFORMASI KESEHATAN REPRODUKSI DENGAN SIKAP DAN PERILAKU SEKSUAL PRA NIKAH REMAJA DI SMAN 1 KAUR TAHUN 2017}

\author{
CORRELATION BETWEEN THE UTILIZATION OF HEALTHY REPRODUCTION \\ INFORMATION SOURCE WITH PRE-MARRIED SEX ATTITUDE AND ACT ON \\ ADOLESCENT AT SMAN 1 KAUR IN 2017
}

\author{
IDA SAMIDAH, MURWATI, ERWIN YUHASRI \\ SEKOLAH TINGGI ILMU KESEHATAN DEHASEN BENGKULU
}

\begin{abstract}
ABSTRAK
Menurut SKDI 2012 kesehatan reproduksi menunjukkan bahwa pada umumnya anak laki-laki remaja menyatakan lebih banyak mengetahui pra-menikah dari pada wanita, dibandingkan tahun 2007, persentase pada tahun 2012 cenderung meningkat kecuali pada wanita usia 15-19 tahun. Banyak faktor yang berpengaruh pada perilaku seksual remaja termasuk penggunaan akses informasi dan sikap remaja terhadap perilaku seksual. Tujuan penelitian ini untuk mengetahui hubungan antara penggunaan sumber informasi kesehatan reproduksi dengan perilaku dan perilaku seksual pranikah pada remaja di SMA Negeri 1 Kaur pada tahun 2017. Metode penelitian yang digunakan dalam penelitian ini adalah penelitian analitik dengan rancangan cross-sectional. Sampel penelitian ini sebanyak 80 responden diambil dengan teknik Stratifaid Random Sampling. Hasil penelitian ini menunjukkan bahwa hampir setengah dari responden $(42,4 \%)$, belum dapat memanfaatkan sumber informasi tentang kesehatan reproduksi. Lebih dari separuh responden (51,5\%) memiliki sikap kurang baik, hampir setengah dari responden $(39,4 \%)$ memiliki perilaku seksual berisiko. Ada hubungan antara pemanfaatan sumber informasi kesehatan reproduksi dengan sikap seks pranikah pada remaja di SMA Negeri 1 Kaur $2017(\mathrm{p}=0,000)$ dan ada hubungan antara penggunaan sumber informasi kesehatan reproduksi dengan perilaku seksual pranikah pada remaja di SMA Negeri 1 Kaur tahun 2017 (p $=0,005)$. Disarankan kepada pihak SMAN 1 Kaur dapat meningkatkan nilai agama kepada siswa melalui program spiritual sesuai dengan kepercayaan siswa dan diharapkan kepada SMAN 1 Kaur dapat melakukan atau memperbaiki konseling tentang kesehatan reproduksi dalam kerjasama dengan instansi kesehatan.

Kata Kunci: pemanfaatan sumber informasi, kesehatan reproduksi, sikap, prilaku, pranikah, remaja
\end{abstract}

\begin{abstract}
According to SKDI 2012 Adolescent Reproductive Health shows that in general adolescent boys stated more pre-married sex than women, compared to 2007, the percentage in 2012 tends to increase except in women 15-19 years. Many factors that have effect on adolescent sexual behavior include the use of information access and adolescent attitudes toward sexual behavior. The purpose of this study to determine the relationship between the use of reproductive health information resources with premarital sexual attitudes and behavior in adolescents in SMA
\end{abstract}


Negeri 1 Kaur in 2017. The research method used in this research is analytical research using cross-sectional design. The sample of this study as many as 80 respondents taken by Stratifaid Random Sampling technique. The results of this study indicate that almost half of the respondents $(42.4 \%)$, are not good at utilizing sources of information about reproductive health. More than half of respondents $(51.5 \%)$ have unfavorable attitudes, almost half of respondents (39.4\%) Have risky sexual behavior. There is a relationship between the utilization of reproductive health information sources with attitudes about premarital sex in adolescents at SMA Negeri 1 Kaur $2017(\mathrm{p}=0,000)$ and there is a relationship between the use of reproductive health information resources with premarital sexual behavior in adolescents in high school Country 1 Kaur year $2017(\mathrm{p}=0.005)$. It is suggested to the SMAN 1 Kaur party is expected to increase the value of religion to the students through the spiritual program in accordance with the belief of students and is expected to the SMAN 1 Kaur can do or improve the counseling about reproductive health in cooperation with health intansi.

Keywords: the utilization of information source, healthy reproduction, attitude, act, premarried sex, adolescent

\section{PENDAHULUAN}

Menurut World Health Organization (WHO) tahun 2013 menyebutkan bahwa angka kejadian hamil tanpa hubungan pernikahan sebesar 11 persen dan angka kejadian aborsi sekitar 1000 kasus akibat gangguan kehamilan maupun akibat kehamilan tidak dikehendaki. Menurut data kejadian aborsi ini juga didapatkan data kasus aborsi sebesar 49 persen yang dilakukan secara non medis.

Sumber informasi bagi remaja dalam mendapatkan informasi tentang kesehatan reproduksi remaja tidak hanya dari orang tua atau guru tetapi juga bisa dari media masa. Sebuah penelitian menunjukkan remaja lakilaki yang mendapat informasi dengan melihat buku porno $59,3 \%$ dan menonton film porno $48,8 \%$, sedangkan pada wanita $28,4 \%$ mendapat informasi dengan melihat buku porno, dan 15,9\% menonton film porno (Yahya, 2009).

Perkembangan zaman, pengaruh globalisasi, termasuk kontrol sosial dan keyakinan akan nilai agama yang mulai mengendur juga mempengaruhi sikap dan perilaku remaja. Hubungan seks sebelum nikah yang sebelumnya sangat ditabukan menjadi hal yang dinilai wajar dilakukan ketika berpacaran dan sebagian sikap remaja setuju terhadap hubungan seks sebelum menikah (Natalia, 2012). Adapun yang dimaksud dengan sikap permisif sikap mendukung terhadap perilaku seksual ditunjukkan dalam gaya berpacaran yang "serba boleh", mulai dari berciuman hingga akhirnya hubungan seksual dan sikap tersebut disepakati oleh kedua belah pihak atau "mau sama mau" (Damayanti, 2007).

Berdasarkan hasil wawancara yang dilakukan peneliti di SMA Negeri 1 Kaur, dari 10 siswa yang dilakukan wawancara, 1 orang siswa mengakui belum pernah melakukan ciuman dan pelukan selama pacaran. Ketika penulis menanyakan apakah pernah melihat video porno, semuanya mengungkapkan pernah melihat dari VCD, majalah porno dan handphone. Kemudian 2 dari 10 siswa mengatakan mereka mendapat informasi mengenai seks didapat dari orang tua, dan 8 dari 10 siswa mengatakan mendapat informasi kesehatan dari guru, lingkungan tempat tinggal, dan media internet. Mereka mengatakan orang tua tidak pernah memberikan informasi kepada mereka.

Berdasarkan latar belakang diatas, maka yang menjadi perumusan masalah dalam penelitian ini adalah apakah terdapat hubungan antara pemanfaatan sumber informasi kesehatan reproduksi dengan sikap dan perilaku seksual pranikah pada remaja di SMA Negeri 1 Kaur tahun 2017. 


\section{METODE PENELITIAN}

Jenis penelitian ini adalah penelitian secara analitik dengan menggunakan desain cross-sectional yang merupakan rancangan penelitian dengan melakukan pengukuran atau pengamatan pada saat bersamaan (sekali sewaktu) antara faktor resiko (sumber informasi) atau variabel independen dengan efek atau variabel dependent (sikap dan perilaku seksual remaja).

Sumber data yang digunakan dalam penelitian ini diperoleh peneliti dengan menggunakan wawancara. Sumber data primer berasal dari koesioner pertanyaan yang dibuat oleh peneliti dan diberikan kepada responden.

\section{HASIL PENELITIAN}

\section{Analisa Univariat}

Anailis univariat pada penelitian ini untuk melihat distribusi frekuensi variabel penelitian yaitu pemanfaatan sumber informasi kesehatan reproduksi, sikap dan perilaku seksual pranikah pada remaja yang dapat dilihat pada tabel berikut:

Tabel 1 Distribusi frekuensi pemanfaatan sumber informasi yang diperoleh remaja di SMA Negeri 1 Kaur tahun 2017

\begin{tabular}{ccc}
\hline $\begin{array}{c}\text { Pemanfaatan } \\
\text { Sumber Informasi }\end{array}$ & Frekuensi & Persentase \\
\hline Tidak Baik & 28 & 42,4 \\
\hline Baik & 38 & 57,6 \\
\hline Total & 66 & 100,0 \\
\hline
\end{tabular}

Berdasarkan tabel 1 diketahui bahwa lebih dari setengah responden $(57,6 \%)$, baik dalam memanfaatkan sumber informasi tentang kesehatan reproduksi.

Tabel 2 Distribusi frekuensi sikap tentang seksual pranikah pada remaja di SMA Negeri 1 Kaur tahun 2017

\begin{tabular}{ccc}
\hline Sikap & Frekuensi & Persentase \\
\hline Unfavorabel & 34 & 51,5 \\
\hline Favorabel & 32 & 48,5 \\
\hline Total & 66 & 100,0 \\
\hline
\end{tabular}

Berdasarkan tabel 2 diketahui bahwa lebih dari setengah responden $(51,5 \%)$, mempunyai sikap unfavorabel.

Tabel 3 Distribusi frekuensi perilaku seksual pada remaja di SMA Negeri 1 Kaur tahun 2017

\begin{tabular}{ccc}
\hline Perilaku Seksual & Frekuensi & Persentase \\
\hline Beresiko & 26 & 39,4 \\
\hline Tidak Beresiko & 40 & 60,6 \\
\hline Total & 66 & 100,0 \\
\hline
\end{tabular}

Berdasarkan tabel 3 diketahui bahwa lebih dari setengah responden $(60,6 \%)$ memiliki perilaku seksual tidak beresiko.

\section{Analisa Bivariat}

Anailis bivariat pada penelitian ini untuk melihat hubungan antara pemanfaatan sumber informasi kesehatan reproduksi dengan sikap dan perilaku seksual pranikah pada remaja di SMA Negeri 1 Kaur tahun 2017 yang dapat dilihat pada tabel berikut:

Tabel 4 Hubungan antara pemanfaatan sumber informasi kesehatan reproduksi dengan sikap tentang seksual pranikah pada remaja di SMA Negeri 1 Kaur tahun 2017

\begin{tabular}{|c|c|c|c|c|c|c|}
\hline \multirow{3}{*}{$\begin{array}{c}\text { Variabel } \\
\text { Sumber } \\
\text { Informasi }\end{array}$} & \multicolumn{5}{|c|}{$\begin{array}{c}\text { Sikap Tentang Seksual } \\
\text { Pranikah }\end{array}$} & \multirow[t]{3}{*}{$\underset{\text { Value }}{p}$} \\
\hline & \multicolumn{4}{|c|}{ Unfavorabel favorabel } & Total & \\
\hline & $f$ & $\%$ & $\mathbf{f}$ & $\%$ & f $\%$ & \\
\hline Tidak Baik & 27 & 96,4 & 1 & 3,6 & 28100,0 & \\
\hline Baik & 7 & 18,4 & 31 & 81,6 & $\overline{38100,0}$ & 0,000 \\
\hline
\end{tabular}

Berdasarkan tabel 4 diketahui bahwa dari 28 responden yang memanfaatkan sumber informasi tentang kesehatan reproduksi yang 
tidak baik terdapat $27(96,4 \%)$, responden yang mempunyai sikap unfavorabel Tentang Seksual Pranikah dan dari 38 responden yang memanfaatkan sumber informasi tentang kesehatan reproduksi yang baik terdapat 7 $(18,4 \%)$, yang mempunyai sikap unfavorabel tentang seksual pranikah. Hasil analisis chisquare menunjukkan bahwa nilai $p=0,000$ lebih kecil dari nilai alpha 0,05 artinya ada hubungan antara pemanfaatan sumber informasi kesehatan reproduksi dengan sikap tentang seksual pranikah pada remaja di SMA Negeri 1 Kaur tahun 2017.

Tabel 5 Hubungan antara pemanfaatan sumber informasi kesehatan reproduksi dengan perilaku seksual pranikah pada remaja di SMA Negeri 1 Kaur tahun 2017

\begin{tabular}{|c|c|c|c|c|c|c|c|}
\hline Variabel & \multicolumn{4}{|c|}{$\begin{array}{c}\text { Perilaku Seksual } \\
\text { Remaja }\end{array}$} & & & \multirow[t]{2}{*}{$\underset{\text { Value }}{p}$} \\
\hline \multirow{2}{*}{$\begin{array}{l}\text { Sumber } \\
\text { Informasi }\end{array}$} & Ber & siko & $\begin{array}{r}\text { Ti } \\
\text { Ber }\end{array}$ & $\begin{array}{l}\text { ak } \\
\text { siko }\end{array}$ & & tal & \\
\hline & $f$ & $\%$ & $\mathrm{f}$ & $\%$ & $\mathrm{f}$ & $\%$ & \\
\hline Tidak baik & 17 & 60,7 & 11 & 39,3 & 28 & 100,0 & 0,005 \\
\hline Baik & 9 & 23,7 & 29 & 76,3 & 38 & $\overline{100,0}$ & \\
\hline
\end{tabular}

Berdasarkan tabel 5 diketahui bahwa dari 28 responden yang memanfaatkan sumber informasi kesehatan reproduksi tidak baik terdapat $17 \quad(60,7 \%)$, responden yang mempunyai perilaku seksual beresiko dan dari 38 responden yang memanfaatkan sumber informasi kesehatan reproduksi baik terdapat $9(23,7 \%)$, responden yang mempunyai perilaku seksual beresiko. Hasil analisis chi-square menunjukkan bahwa nilai $p=0,005$ lebih kecil dari nilai alpha 0,05 artinya ada hubungan antara pemanfaatan sumber informasi kesehatan reproduksi dengan perilaku seksual pranikah pada remaja di SMA Negeri 1 Kaur tahun 2017.

\section{PEMBAHASAN}

1. Gambaran pemanfaatan sumber informasi yang diperoleh remaja di SMA Negeri 1 Kaur tahun 2017
Hasil penelitian ini diketahui bahwa hampir dari sebagian responden $(42,4 \%)$, tidak baik dalam memanfaatkan sumber informasi tentang kesehatan reproduksi dan lebih dari separuh responden $(57,6)$ baik dalam memanfaatkan sumber informasi tentang kesehatan reproduksi. Berdasarkan hasil penelitian ini dapat disimpulkan bahwa secara keseluruhan remaja di SMAN 1 Kaur sudah memanfaatkan sumber informasi tentang kesehatan reproduksi dengan baik, sumber informasi yang paling banyak dimanfaatkan oleh remaja yaitu dari orang tua dan dari guru.

\section{Gambaran sikap tentang seksual pranikah pada Remaja Di SMA Negeri 1 Kaur Tahun 2017}

Hasil penelitian ini menunjukkan bahwa lebih dari setengah responden (51,5\%), mempunyai sikap unfavorabel tentang seksual pranikah pada remaja dan hampir dari sebagian responden mempunyai sikap favorabel terhadap tentang seksual pranikah pada remaja.

Sedangkan hasil penelitian Widyastuti, (2010) di SMU Bhakti Ibu 8 palembang yang menunjukkan bahwa responden yang bersikap kurang baik sebanyak 29 orang $(34,5 \%)$ dan sebagian besar responden yang bersikap baik sebanyak 55 orang $(65,5 \%)$. Hasil penelian ini menunjukkan adanya perbedaan, perbedaaan ini terlihat dari persentase sikap responden, keadaan ini dapat terjadi karena adanya perbedaan karakteristik responden yang diteliti seperti keadaan wilayah maupun keadaan lingkungan pergaulan remaja.

Masih banyaknya remaja yang mempunyai sikap unfavorabel terhadap perilaku seksual pranikah dapat berpengaruh buruk terhadap perilaku seksual pranikah pada remaja. Masih bayaknya remaja yang mempunyai sikap yang unfavorabel keadaan ini sangat memprihatinkan karena dengan adanya sikap yang unfavorabel terhadap perilaku seksual pranikah yang baik dapat mendukung perilaku seksualitas yang tidak baik dari remaja yang dapat menyebabkan 
berbagai masalah seperti kehamilan diluar nikah terganggunya masalah psikologis dan lain sebagainya. Sikap yang lebih cenderung tidak mendukung terhadap perilaku seksualitas yang baik pada remaja ini dapat disebabkan oleh berbagai faktor seperti lingkungan pergaulan yang menuntut remaja mengikuti perkembangan zaman.

\section{Gambaran perilaku seksual pada remaja di SMA Negeri 1 Kaur tahun 2017}

Hasil penelitian ini diketahui bahwa hampir sebagian responden $(39,4 \%)$ memiliki perilaku seksual yang beresiko memiliki perilaku seksual yang beresiko dan lebih dari setengah responden $(60,6 \%)$ memiliki perilaku seksual yang beresiko. Hasil penelitian ini menggambarkan bahwa remaja yang mempunyai perilaku seksual beresiko masih cukup tinggi, adapun perilaku seksual yang paling banyak ditunjukkan remaja dengan pacar biasa berpegangan tangan, remaja mengatakan mencium pipi pacar sebagai bentuk rasa sayang, berpelukan dengan pacar dilakukan saat jalan-jalan dan berciuman bibir dengan pacar setiap ada kesempatan.

Berdasarkan hasil penelitian dapat dijelaskan bahwa remaja yang mempunyai perilaku seksual yang beresiko paling banyak belum mencapai tindakan hubungan badan walaupun ada sebagian kecil remaja yang mengatakan melakukan hubungan seksual. Masih banyaknya remaja yang menunjukkan perilaku seksual yang beresiko ini dapat terjadi karena mudahnya akses media pornografi, rasa ingin mencoba yang tinggi sesuatu yang baru dari remaja ataupun kurangnya pengetahuan remaja mengenai perilaku seksual.

\section{Hubungan antara pemanfaatan sumber informasi kesehatan reproduksi dengan sikap tentang seksual pranikah pada remaja di SMA Negeri 1 Kaur tahun 2017.}

Hasil penelitian ini menunjukkan bahwa ada hubungan antara pemanfaatan sumber informasi kesehatan reproduksi dengan sikap tentang seksual pranikah pada remaja di SMA Negeri 1 Kaur tahun $2017(p=0,000)$. Hasil penelitian ini dapat disimpulkan bahwa pemanfaatan informasi oleh remaja sangat berpengaruh terhadap sikap remaja tentang seksual pranikah.

Hasil penelitian ini sesuai dengan pendapat Azwar (2013), yang menyatakan bahwa adanya informasi baru mengenai sesuatu hal akan memberikan landasan kognitif baru bagi terbentuknya sikap terhadap hal tersebut, pesan-peasan sugestif yang dibawa oleh informasi tersebut, apabila cukup kuat, akan memberi dasar afektif dalam suatu hal sehingga terbentuklah arah sikap tertentu.

Hasil penelitian ini sesuai dengan penelitian Shanti (2014) dengan judul penelitian hubungan sumber informasi tentang seksualitas dengan sikap remaja tentang seksual pranikah menunjukkan bahwa ada hubungan yang signifikan antara sumber informasi tentang seksualitas dengan sikap remaja mengenai seksual pranikah di kelas XI SMA Negeri 1 Sewon Bantul Yogyakarta tahun $2014(\mathrm{p}=0,037)$.

Hasil penelitian ini juga menunjukkan bahwa hampir dari sebagian kecil reponden $(18,4 \%)$ yang memanfaatkan sumber informasi yang baik masih mempunyai sikap yang unfavorabel tentang seksual pranikah. Hal ini dapat terjadi karena tidak semua orang yang mendapat informasi yang baik akan berpengaruh terhadap pengetahuan yang baik yang dapat berpengaruh terhadap sikap yang baik juga terhadap sikap remaja tersebut. Selain itu remaja keadaan ini dimungkinkan adanya pengaruh dari teman sebaya remaja yang mempengaruhi remaja terhadap perilaku seksual dimana, teman sebaya mempunyai pengaruh yang besar terhadap sudut pandang remaja tentang perilaku seksual.

5. Hubungan antara pemanfaatan sumber informasi kesehatan reproduksi dengan perilaku seksual pranikah pada remaja di SMA Negeri 1 Kaur tahun 2017. 
Hasil penelitian ini menunjukkan bahwa ada hubungan antara pemanfaatan sumber informasi kesehatan reproduksi dengan perilaku seksual pranikah pada remaja di SMA Negeri 1 Kaur tahun $2017(p=0,005)$.

Hasil penelitian ini dapat disimpulkan bahwa adanya pemanfaatan informasi yang baik oleh remaja dapat mempengaruhi perilaku seksual pranikah pada remaja, Hal ini dapat terjadi karena dengan adanya pemanfaatan sumber informasi yang baik remaja akan mendapat pengetahuan tentang kesehatan reproduksi yang akan berdampak kepada sikap remaja yang pada ahirnya dapat berpengaruh terhadap perilaku perilaku seksual pranikah pada remaja.

Hasil penelitian ini sesuai dengan pendapat Moeliono, (2008), kesehatan reproduksi pada remaja memberikan berbagai informasi penting dan benar menyangkut kesehatan reproduksinya, remaja akan lebih memahami perkembangan dan perubahan yang akan dialaminya dan karenanya siap menghadapinya. Remaja berhak memperoleh informasi yang benar, objektif, akurat, jujur mengenai kesehatan reproduksi dan seksualitas.

\section{KESIMPULAN}

Berdasarkan hasil penelitian tentang hubungan antara pemanfaatan sumber informasi kesehatan reproduksi dengan sikap dan perilaku seksual pranikah pada remaja di SMA Negeri 1 Kaur tahun 2017 dapat ditarik kesimpulan sebagai berikut:

1. Lebih dari setengah responden, baik dalam memanfaatkan sumber informasi tentang kesehatan reproduksi.

2. Lebih dari setengah responden, mempunyai sikap unfavorable.

3. Lebih dari setengah responden memiliki perilaku seksual yang tidak beresiko.

4. Ada hubungan antara pemanfaatan sumber informasi kesehatan reproduksi dengan sikap tentang seksual pranikah pada remaja di SMA Negeri 1 Kaur tahun $2017(p=0,000)$.

5. Ada hubungan antara pemanfaatan sumber informasi kesehatan reproduksi dengan perilaku seksual pranikah pada remaja di SMA Negeri 1 Kaur tahun 2017 $(p=0,005)$.

\section{SARAN}

Berdasarkan hasil penelitian yang telah dilakukan maka peneliti memberi saran kepada:

1. SMAN 1 Kaur

Kepada pihak SMAN 1 Kaur diharapkan dapat meningkatkan nilai agama kepada peserta didiknya melalui program kerohanian sesuai dengan keyakinan siswa didik dan diharapkan kepada pihak SMAN 1 Kaur dapat melakukan ataupun meningkatkan penyuluhan tentang kesehatan reproduksi dengan bekerja sama dengan intansi kesehatan.

2. STIKes Dehasen.

Kepada pihak akademik diharapkan dapat ikut andil dalam upaya meningkatkan pengetahuan remaja tentang perilaku seksualitas sehingga menanamkan moral kepada para remaja dalam menyikapi perilaku seksualitas dengan cara membimbing mahasiswa melakukan penyuluhan-penyuluhan kesehatan reproduksi ke sekolah-sekolah.

3. Kepada Peneliti Selanjutnya

$$
\text { Kepada peneliti selanjutnya }
$$
diharapkan agar berupaya lebih mengembangkan dan memperdalam bahasan tentang faktor yang mempengaruhi perilaku seksual remaja dengan mempertimbangkan dan faktor lain seperti peran orang tua, guru, maupun nilai agama dengan memperluas ruang lingkup penelitian untuk mendapatkan 
hasil yang lebih baik lagi.

\section{DAFTAR PUSTAKA}

Andani. 2011. Ilmu Kesehatan Masyarakat.Nuha Medika: Yogyakarta

Azwar. 2013. Sikap Manusia: Teori dan Pengukurannya. Pustaka Pelajar: Yogyakarta.

Arsyad. 2007. Media Pembelajaran. Raja Grafindo Persada: Jakarta.

BKKBN, 2008. Penyiapan Kehidupan Berkeluarga Bagi Remaja. BKKBN : Jakarta

Damayanti, R. 2007. Peran Biopsikososial Terhadap Perilaku Berisiko Tertular Hiv Pada Remaja SLTA di DKI Jakarta.: FKM UI. Jakarta.

Dewi, 2012. Hubungan Karakteristik Remaja, Peran Teman Sebaya dan Paparan Pornografi dengan Perilaku Seksual Remaja di Kelurahan Pasir Gunung Selatan Depok. Tesis.FakultasIlmuKeperawatan Universitas Indonesia.

Eka. 2012. Memahami Perkembangan Fisik Remaja, Gosyen Publishing: Yogyakarta.

Ernawati. 2014. Pemanfaatan Orang Tua Sebagai Sumber Informasi Kesehatan Reproduksi Remaja Di Daerah Pedesaan. Jurusan S1 Keperawatan, FIK Universitas Muhammadiyah Ponorogo

Hambali. 2008. Mensosialisasikan Pendidikan Seks untuk Remaja.Jender dan Kesehatan. Berita Berkala. Vol. No. 6, hal. 29-30

Hidayat. 2012. Metode Penelitian Kebidanan Teknik Analisa Data. Salemba Medika: Jakarta.

Irawati dkk. 2013. Studi Akses Terhadap Media Kesehatan Reproduksi Pada Kalangan Remaja Di Sma Negeri 9 Bulukumba Kabupaten Bulukumba. Fakultas Kesehatan Masyarakat Universitas Hasanuddin

Irianto. 2013. Permasalahan Seksualitas. Yrama Widya: Bandung.

Julius. 2013. Hubungan Peran Orang Tua dan Sumber Informasi dengan Perilaku
Seksual Remaja di SMAN 15 Semarang. Program Studi S1 Keperawatan Fakultas Ilmu Keperawatan dan Kesehatan Universitas Muhammadiyah Semarang

Kusmiran. 2012. Kesehatan Reproduksi Remaja dan Wanita. Salemba Medika: Jakarta

Liliweri, A. 2007. Dasar-dasar Komunikasi Kesehatan. Yogyakarta: Pustaka Pelajar.

Mentari. 2011. Hubungan Sumber Informasi dan Pengetahuan tentang Kesehatan Reproduksi dengan Perilaku Seks Bebas Pada Remaja di SMP Muhammadiyah 7 Surakarta. Skripsi. Universitas Muhammadiyah Surakarta.

Mubarak. 2012. Promosi Kesehatan Untuk Kebidanan. Salemba Medika: Jakarta

Moeliono. 2008. Proses belajar aktif : Komunikasi, Informasi dan Edukasi (KIE) kesehatan reproduksi remaja bagi anak usia 11-15 tahun. Jakarta.

Natalia, 2012. Faktor-faktor yang mempengaruhi perilaku seks pra nikah pada mahasiswa akademi kesehatan $x d i$ kabupaten lebak. Tesis. Program pasca sarjana Program studi ilmu kesehatan masyarakat Fakultas kesehatan masyarakat. Depok.

Notosoedirdjo. 2008. Kesehatan Mental: Konsep dan Penerapan. Malang: Penerbit Universitas Muhammadiyah: Malang

Notoatmodjo, 2010. Metodologi Penelitian Kesehatan. Rineka Cipta. Jakarta

Notoatmodjo. 2010. Ilmu Perilaku Kesehatan. Rineka Cipta. Jakarta.

Notoatmodjo. 2011. Ilmu kesehatan masyarakat ilmu \& Seni. Rineka Cipta. Jakarta

Potter \& Perry. 2010. Buku Ajar Fundamental Keperawatan, Konsep, Proses dan Praktik. EGC. Jakarta.

Santrock. 2010. Life-Span Development: Perkembangan Masa-Hidup. Edisi 13. Jilid 1. Alih Bahasa: Widyasinta Benedictine. Jakarta: Erlangga.

Sarwono. 2012. Psikologi Remaja. PT Raja Grafindo Persada: Jakarta.

Singgih. 2008. Psikologi Praktis, Anak, 
Remaja dan Keluarga. BPK Gunung Mulia: Jakarta.

Siregar, S., 2011, Statistika Deskriptif untuk Penelitian, PT. Raja Grafindo Persada: Jakarta

Sugiyono. 2008. Metode Penelitian Kunatitatif Kualitatif dan R\&D. Alfabeta: Bandung.

Willis, S. S. 2008. Remaja dan Masalahnya. ALFABETA: Bandung.

Wijdayanti. 2009. Gambaran Umur dan Perilaku Remaja Tentang Seks Pranikah Pada Pelajar SMA di Kota Semarang. Semarang : Universitas Muhammadiyah Semarang.

Widianto. 2007. Hubungan Peran Orang Tua Dalam Pendidikan Kesehatan Reproduksi Dengan Sikap Tentang Seks Bebas Pada Siswa Kelas II Di SMU 3 PGRI Randudongkal Pemalang. Jurusan Fakultas Ilmu Keperawatan Universitas Muhammadiyah Semarang.

Yusuf, P. M. 2010. Komunikasi Instruksional : teori dan praktek. PT. Bumi Aksara: Jakarta

Yuni. 2013. Kebutuhan Informasi Wanita Pekerja Seks Di Resosialisasi Argorejo Semarang. Thesis. Universistas Diponegoro. Semarang 